\title{
Vertebrates used for medicinal purposes by members of the Nyishi and Galo tribes in Arunachal Pradesh (North-East India)
}

\author{
Jharna Chakravorty ${ }^{1,2}$, V Benno Meyer-Rochow ${ }^{2^{*}}$ and Sampat Ghosh ${ }^{1}$
}

\begin{abstract}
Arunachal Pradesh, the easternmost part of India, is endowed with diverse natural resources and inhabited by a variety of ethnic groups that have developed skills to exploit the biotic resources of the region for food and medicines. Information on animals and animal parts as components of folk remedies used by local healers and village headmen of the Nyishi and Galo tribes in their respective West Siang and Subansiri districts were obtained through interviews and structured questionnaires. Of a total of 36 vertebrate species used in treatments of ailments and diseases, mammals comprised 50\%; they were followed by birds (22\%), fishes (17\%), reptiles (8\%) and amphibians (3\%). Approximately 20 common complaints of humans as well as foot and mouth disease of cattle were targets of zootherapies. Most commonly treated were fevers, body aches and pains, tuberculosis, malaria, wounds and burns, typhoid, smallpox, dysentery and diarrhoea, jaundice, and early pregnancy pains. Very few domestic animal species (e.g., goat and cattle) were used zootherapeutically. More frequently it was wild animals, including endangered or protective species like hornbill, pangolin, clouded leopard, tiger, bear, and wolf, whose various parts were either used in folk remedies or as food. Some of the animal-based traditional medicines or animal parts were sold at local markets, where they had to compete with modern, western pharmaceuticals. To record, document, analyze and test the animal-derived local medicines before they become replaced by western products is one challenge; to protect the already dwindling populations of certain wild animal species used as a resource for the traditional animal-derived remedies, is another.
\end{abstract}

\section{Introduction}

Scientific research is revealing an ever increasing number of links between biodiversity and human health, not only in terms of food resources or food security, but also with regard to materials to treat and cure diseases. Since ancient time plants and animals, or parts of them, have been used therapeutically and even today animal and plant-based medicines continue to play an essential role in world health care [1]. Although plant and plantderived materials have received considerably more attention from scientists and are more commonly used in traditional medical systems than animal-derived products, the latter also constitute an important element in the materialia medica. In fact, the use of animals for medicinal purposes is part of a body of traditional

\footnotetext{
* Correspondence: b.meyer-rochow@jacobs-university.de

${ }^{2}$ School of Engineering and Science, Jacobs University, Research II (Rm. 37) D-28759 Bremen, Germany

Full list of author information is available at the end of the article
}

knowledge, which is becoming more and more relevant to discussions on mammalian relationships and phylogeny [2], conservation biology, biological prospecting, and patenting [3-6]. It has been reported that more than half of the world's modern drugs are of biological sources $[7,8]$ and that of the 252 chemicals that have been selected by the WHO as essential to human health, 8.7\% come from animal sources [7].

It is fair to say that animals have been playing a significant role in healing processes, folk rituals, and religious practices of peoples from all five continents [6,9-12]. In traditional Chinese Medicine more than 1500 animal species have been recorded to be of some medicinal use $[13,14]$. A list of 60 different species of insects used to treat a wide range of disabilities and illnesses in Japan has been published [15] and 24 animal species were identified, whose by-products were used therapeutically by the Tamang people of Nepal [16]. In Pakistan, 31 animal-derived substances were said to constitute $9 \%$ of

\section{Ciomed Central}


the total of the medicinal substances in the inventory of traditional healers [17]. Alves [18] conducted a study to review traditional treatments of a variety of ailments in North-East Brazil and recorded 250 animal species used in this context and Alves et. al. [19] reported that at least 165 reptile species were used in traditional folk medicines around the world.

In India, since times immemorial, investigations focused on various zootherapies and traditional medicines, documented in the ancient texts of the Ayurveda and Charaka Samhita. Because of its variety in geographic and climatic conditions, India is blessed with diverse flora and fauna, different tribal and ethnic communities, a multitude of cultural complexities. This rich diversity of traditional life styles and biological resources in the different states has permitted gathering together a wealth of ethnozoological knowledge. Yet, the documents containing these diverse pieces of ethnozoological information have been very fragmentary, so that Mahawar and Jaroli [20] conducted a review in which they documented approximately 109 animal species used in the treatment of different kinds of ailments in the whole of India. In another study, but restricted to the adjoining areas of the wild life sanctuary of Mount Abu, 24 animal species were reported to be of medicinal use [21]. Their investigation highlighted the variety of zootherapeutic uses among the tribes of India, especially those of Rajasthan, Maharashtra, Kerala, Andhra Pradesh, parts of Assam and Nagaland. Local uses of amphibians by inhabitants of the Arun Basin [22] and traditional zootherapeutic treatments among the tribal population of Tamil Nadu [23] were reported and ethnomedicinal uses of fish and other aquatic animals are known from Bangladesh [24]. Mishra et al [25] very recently described zoomedicinal uses from Orissa locals that involved animal parts of 7 species of vertebrates to treat 12 different illnesses. Work on the ethnic people of Arunachal Pradesh, however, has till now received only very scant attention (e.g., [26,27] and is in dire need of supplementary information.

Although traditional treatments, making use of animals or animal parts, have often been considered mere superstition, their persistence over hundreds or even thousands of years ought to be sufficient incentive to probe whether or not they are effective. And sure enough, the potency of at least some traditional medicines based on animals cannot be denied, since numerous such medicines have been methodically tested by pharmaceutical companies and turned into sources of drugs, which are now part of the armament of the modern healer [28]. For instance, peptides extracted from scraped secretions of Phyllomedusa bicolor (Amphibians), are used in the treatment of depression, stroke, seizures and cognitive loss in ailments such as
Alzheimer's disease [29]. Early muscle relaxants were obtained from so-called poison arrow frogs, containing curare, a compound also used in psychiatric treatments [30]. The deer velvet extract pantocrin is nowadays marketed as a powerful antioxidant with anti-stress and immunomodulatory activity for use with humans [31] and animals, e.g. dogs [32].

Actually, while some uses of animals and their products as components of traditional medicines still remain unrecorded, the list of animals that can be used to obtain therapeutically important compounds from grows. Thus, we have a problem: the scholarly investigation of studies on the medicinal uses of animals and their products should not be neglected and ought to be considered a legitimate and important quest to complement the existing body of knowledge. On the other hand, species deemed most useful in this regard can easily be overexploited and become threatened by extinction [33].

The increasing relevance of ethnobiological knowledge across the globe and, on the other hand, the danger of losing this information before it can be properly documented, prompted us to embark on this study to record to what extent members of the Nyishi and Galo tribes of Arunachal Pradesh in the northeastern part of India make use of animals and their products in treatments of common ailments and diseases.

\section{Study Area and Methodology}

Arunachal Pradesh (Figure 1) lies in the north-easternmost part of India and shares a major portion of the biological hot spot region of the Eastern Himalaya owing to its range of vegetation from tropical to alpine. The state is not only rich in floral and faunal diversity, but with 26 major tribes and 110 sub-tribes also in ethnic communities. Forests cover $60 \%$ of the total area of Arunachal Pradesh and the range of geographic, climatic, and cultural diversity has provided the backdrop for the wealth of traditional knowledge in this region of India. Traditional healing practices are one of the treasures of this resource-privileged region. The Nyishi and Galo tribes of Arunachal inhabit mainly the East Kameng (Nyishi) (Figure 2) and West Siang (Galo) (Figure 3) regions of Arunachal Pradesh, where literacy rate is relatively low, but life expectancy is high. Due to limited access to proper medical care and transportation, most of these people hold a traditional knowledge pertaining to the use of natural resources as medicines for community welfare. For their livelihood these tribal people are totally dependent on the forest and its resources.

As with our earlier study [34] data were obtained during visits to ten villages in each of the tribal areas, selected at random. The number of households per village was $12-20$ (one village had 30). Frequently at least 


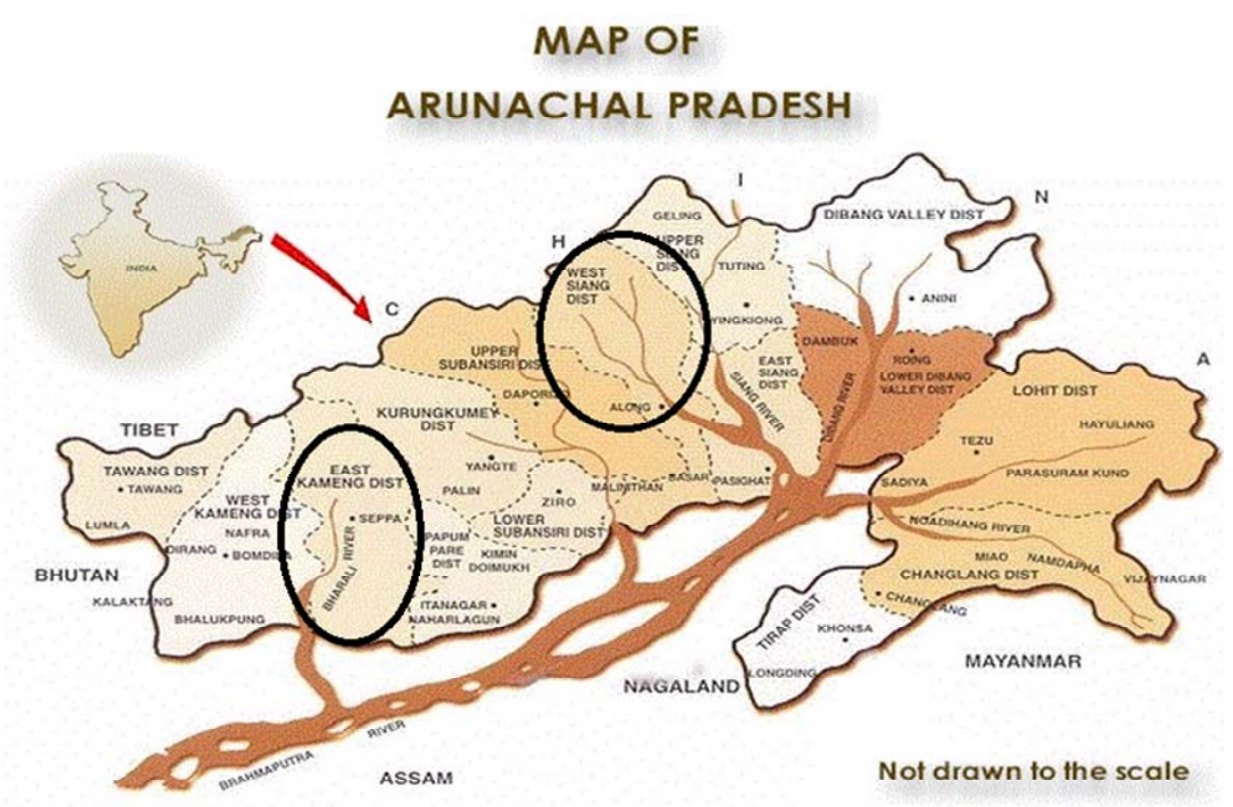

Figure 1 Map of Arunachal Pradesh, showing study sites (for information on latitudes and longitudes, see Figs 1 b,c).

2 houses were unoccupied, because the families had moved into the towns in search of work. At least two households per village, inhabited by village elders and their families, were visited. Recommendations by the headman or village elders to visit certain knowledgeable persons in another village were sometimes followed.

The interviewed people (20 persons aged between 45 and 70 years of age from each tribe) were asked simple questions like "how do you know when you are sick? What tells you that you are sick?". After having obtained a list of the major illnesses that the local people

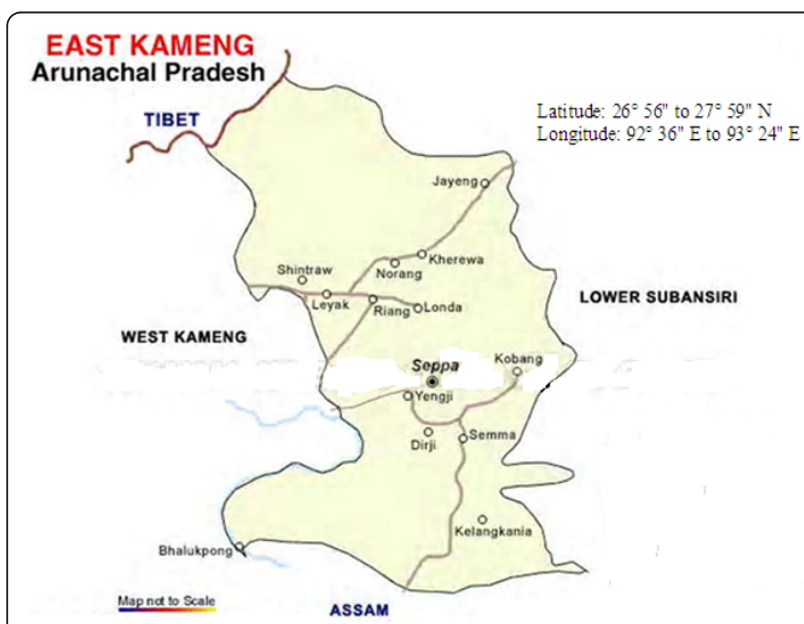

Figure 2 Map showing East Kameng study site. Adopted from: www.mapsofindia.com/maps/arunachalpradesh/districts/eastkameng. htm recognize and distinguish, we asked how they treated a person that suffered from such illnesses. When animals or parts of animals were involved, we requested that these animals be shown to us. In most cases the locals complied and with the help of illustrated identification guides [35-39] it was usually possible to identify the species in question. Where this was not possible, photographs of an animal in question were taken and later shown to an expert or compared with specimens in the university collection. To take voucher specimens back to the university was not possible for three reasons: firstly, many of the species involved are too large to be

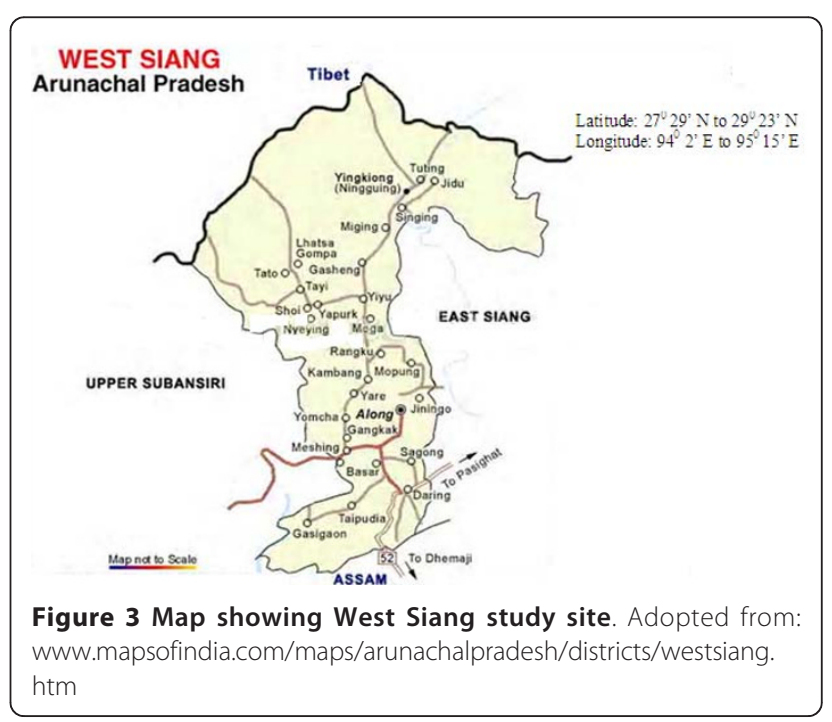


transported (e.g., goats, bulls, bears, porcupines etc); secondly, the locals would not let us take some of the specimens, fearing they could get into trouble; thirdly, many villages visited are so remote that no roads lead to them and one had to walk there, making transport of any material a very difficult undertaking. The vernacular names of the zootherapeutically (or otherwise important) vertebrates were written down phonetically, and notes were taken on the ailments treated with these animals, modes of preparation, assumed therapeutic value, related folklore and anything else considered worthwhile in connection with the species in question. As the knowledge of Hindi or English of the locals was often not great, our questions had to be simple and to the point. Further information was obtained from about 15 persons of Nyishi or Galo origin, regarded as knowledgeable, but living in the urban areas. Their selection as informants was based on the input provided by the villagers. According to the locals, their own knowledge of medicinal animals was acquired through parental heritage, or because they had experienced folk medicine healing their kin and/or themselves. Most people interviewed could come up with at least 8 different zootherapies. However, in order to obtain an idea on how widespread and common the particular zootherapeutic knowledge was, we decided, as with our earlier study [34] to only accept into our list animals and their products when at least $40 \%$ of the respondents answered in the same way.

\section{Results and Discussion}

We examined the traditional zootherapeutic uses that Nyishi and Galo people have for vertebrates and their parts in treating various kinds of diseases of humans and livestock. Table 1 summarizes the scientific names of the medicinally used vertebrates, their vernacular names, the part(s) of the animal used, the diseases or ailments the animal-derived medicines are thought to be effective for, and the ways the treatments are carried out. Table 2 summarizes the present conservation status of the vertebrates mentioned in Table 1 as zootherapeutically important. Altogether 36 species of vertebrates were identified to play a role in the treating humans and animals suffering from a variety of ailments and ills. Out of these 36 species, the use of mammals and their parts was highest, constituting about $50 \%(\mathrm{n}=18)$; next came birds $(\mathrm{n}=8 ; 22.22 \%)$, fish $(\mathrm{n}=6 ; 16.67 \%)$, and reptiles $(\mathrm{n}=3 ; 8.33 \%)$. Amphibians were used least $(\mathrm{n}=1,2.78 \%)$ (Figure 4). In similar studies carried out around the world, mammals and birds also recorded the highest use as part of local folk medicines $[19,20,40-47]$. Surveys other than our own research from north-eastern India indicate the same $[48,49]$. However, for the tribal populations of the Garo hills in Meghalaya (NE India) Sharma and Khan [43] observed that drugs of insect origin were more common than those derived from vertebrates.

Of the zootherapeutic species recorded in the present study either whole animal bodies, body parts, or the animals' products were used. Zootherapeutic animal body parts or their products were assigned to one the following 16 categories of raw materials that formed the basis of medicines and were prescribed for treating locally diagnosed ailments. The 16 categories were: 1 . claws and nails, 2. skin, 3. feathers, 4 . mucus, fins, 6 . fat, 7. flesh, 8 . bone, 9. bone marrow, 10. stomach, 11. intestine, 12 . testes, 13. gall bladder, 14. umbilical cord, 15. blood, 16 . horns and antlers. Frequently the sought-after body parts did not always have to come from the same species. For example gall bladders from seven different species were assumed to be of therapeutic value (Figure 5). Some of the animal-derived medicines and preserved animal body parts are sold at the local traditional tribal markets. Collecting the raw materials involves manual gathering, slaughtering of livestock, or hunting and killing of wild species. Modes of preparation and administration of the animal-based medicines are presented in Table 1.

\section{Types of diseases}

About 20 types of common human ailments/diseases (and foot and mouth disease of cattle) were said to be curable by using some of the aforementioned animal materials (Figure 6). Conditions most widely subjected to animal-derived treatments were fevers, body pains and pains of the joints, diarrhoea, tuberculosis, stomach disorders, constipation, malaria, burns, coughs, wounds, typhoid, smallpox, dysentery, jaundice, stomach ache. The two ethnic groups under study seemed to know only the most common ailments encountered in day-today life. It was also observed by the locals that the treatment of one disease could have an effect, either positive or negative, on other diseases and that body parts of different animals could exert similar effects. To be specific, treatment of tuberculosis, for instance, could involve body parts of any one of these animals: porcupine, deer, fox, or mole. Using a variety of remedies for one and the same ailment and then finding that one of them turns out more potent than the others is a popular strategy [50]. It can lead to the adoption of a particular animal or animal part (depending on availability or accessibility) [51] in connection wit a specific condition. Given the fact that hundreds of plants assumed to possess medicinal effects have been identified from NorthEast India [52,53], one can assume that treatments solely based on animals or animal products are rare and that treatments involving animal material will frequently contain a plant component as well. The role of plants, however, has not been a topic of this study and therefore remains uninvestigated. 
Table 1 Inventory of vertebrate species used for medicinal purposes by members of Nyishi (N) and Galo (G) tribes in Arunachal Pradesh (N E India)

\begin{tabular}{|c|c|c|c|c|c|c|c|c|}
\hline & $\begin{array}{l}\text { Common } \\
\text { names }\end{array}$ & $\begin{array}{l}\text { Vernacular } \\
\text { name }\end{array}$ & $\begin{array}{l}\text { Scientific } \\
\text { name }\end{array}$ & $\begin{array}{l}\text { Used } \\
\text { by } N \\
\text { or } \mathrm{G}\end{array}$ & $\begin{array}{l}\text { Parts } \\
\text { used }\end{array}$ & Indication & Prescription & Uses elsewhere in India \\
\hline \multicolumn{9}{|c|}{ Fish } \\
\hline 1 & Eel & $\operatorname{Ngub}(G, N)$ & Anguilla sp. & $N \& G$ & $\begin{array}{l}\text { Body } \\
\text { mucus }\end{array}$ & Burns & $\begin{array}{l}\text { Body mucus to be applied on } \\
\text { burn areas of the body }\end{array}$ & $\begin{array}{l}\text { Fresh blood is drunk to treat } \\
\text { asthma and general weakness } \\
\text { by Ao tribe of Nagaland [49]. }\end{array}$ \\
\hline 2 & $\begin{array}{l}\text { Fresh } \\
\text { water } \\
\text { fishes }\end{array}$ & Ngui (N) & $\begin{array}{l}\text { Semiplotus sp., } \\
\text { Labeo rohita }\end{array}$ & $\mathrm{N}$ & $\begin{array}{l}\text { Stomach } \\
\& \text { gut }\end{array}$ & $\begin{array}{l}\text { Stomach ache \& } \\
\text { digestive } \\
\text { problems }\end{array}$ & $\begin{array}{l}\text { Intestines \& stomach are } \\
\text { smoked in fire, mixed with } \\
\text { salt and taken with rice } 2-3 \\
\text { times a day. Also taken as a } \\
\text { preventive measure. }\end{array}$ & $\begin{array}{l}\text { Cervical vertebra of L. rohita } \\
\text { are used in urine blockage } \\
\text { problem by the Saharia of } \\
\text { Rajasthan [67]. }\end{array}$ \\
\hline 3 & $\begin{array}{l}\text { Gangetic } \\
\text { goonch }\end{array}$ & Nguri (G) & $\begin{array}{l}\text { Bagarius } \\
\text { bagarius }\end{array}$ & G & $\begin{array}{l}\text { Fins, } \\
\text { bones }\end{array}$ & $\begin{array}{l}\text { Body burns, } \\
\text { Stomach pain }\end{array}$ & $\begin{array}{l}\text { Smoked dried bones/fins are } \\
\text { burnt to ash and applied on } \\
\text { burnt portion twice a day. A } \\
\text { pinch of ash is taken along } \\
\text { with water. }\end{array}$ & - \\
\hline 4 & Catfish & Ngui (G) & Amblyceps sp. & G & Bones & Body burns. & $\begin{array}{l}\text { The cooked fish bones are } \\
\text { burnt to ash and applied to } \\
\text { the burn or wound until } \\
\text { healing is observed. The ashes } \\
\text { can be preserved for further } \\
\text { use. }\end{array}$ & - \\
\hline 5 & $\begin{array}{l}\text { Ballitora } \\
\text { minnow }\end{array}$ & $\begin{array}{l}\text { Ngoka ngui } \\
\text { (N) Nyoka } \\
\text { pagra }(G)\end{array}$ & $\begin{array}{l}\text { Psilorhynchus } \\
\text { ballitora }\end{array}$ & $N \& G$ & $\begin{array}{l}\text { Whole } \\
\text { body }\end{array}$ & Diarrhoea & Smoked, dried fish is eaten & - \\
\hline 6 & $\begin{array}{l}\text { Kingfish }+ \\
\text { earthworm }\end{array}$ & $\begin{array}{l}\text { Ngui }+ \\
\text { tadar (N) }\end{array}$ & $\begin{array}{l}\text { Semiplotus sp. } \\
+ \text { Pheretima } \\
\text { sp. }\end{array}$ & $\mathrm{N}$ & $\begin{array}{l}\text { Whole } \\
\text { body }\end{array}$ & Smallpox & $\begin{array}{l}\text { Cooked with fish and fed to } \\
\text { the children suffering from } \\
\text { smallpox }\end{array}$ & - \\
\hline \multicolumn{9}{|c|}{ Amphibia } \\
\hline 7 & Frog & Taker (N) & Rana sp. & $\mathrm{N}$ & $\begin{array}{l}\text { Whole } \\
\text { body }\end{array}$ & Wound healing & $\begin{array}{l}\text { Live crushed frog is applied to } \\
\text { wounds from insect bites } \\
\text { (must be carried out near fire } \\
\text { place) twice a day. }\end{array}$ & $\begin{array}{l}\text { Skin is used for wound } \\
\text { healing by Ao tribe of } \\
\text { Nagaland [49]. } \\
\text { Flesh is used for wound } \\
\text { healing by Irular, Mudugar, } \\
\text { Kurumber of Western Ghat } \\
\text { Kerala [60]. }\end{array}$ \\
\hline \multicolumn{9}{|c|}{ Reptiles } \\
\hline 8 & Python & Burum $(G, N)$ & $\begin{array}{l}\text { Python } \\
\text { molurus }\end{array}$ & $N \& G$ & Body fats & $\begin{array}{l}\text { Massage for } \\
\text { joint pain }\end{array}$ & $\begin{array}{l}\text { Fats are stored in bamboo } \\
\text { containers and used in body } \\
\text { massage to cure joint pain. }\end{array}$ & $\begin{array}{l}\text { Similar fat used for treatment } \\
\text { of rheumatic pain, toothache } \\
\text { by Irular, Mudugar, Kurumber } \\
\text { tribes of Western Ghat Kerala } \\
\text { [60]. But, fried meat is used to } \\
\text { improve eyesight while } \\
\text { snake's slough is used for } \\
\text { cattle by Garasiya people of } \\
\text { Rajasthan [21]. Fat is reported } \\
\text { in treatments of leprosy by } \\
\text { tribal populations of Tamil } \\
\text { Nadu [61]. }\end{array}$ \\
\hline 9 & Cobra & Tabih (G) & Naja sp. & G & Flesh & $\begin{array}{l}\text { 1. Preventive } \\
\text { 2. Foot and } \\
\text { mouth disease } \\
\text { of cattle } \\
\text { 3. Magical }\end{array}$ & $\begin{array}{l}\text { 1. Cooked meat is taken as } \\
\text { preventive measure for } \\
\text { common diseases like colds, } \\
\text { flues and epidemics. } \\
\text { 2. Raw meat is crushed with } \\
\text { little salt and fed to cattle } \\
\text { suffering from foot and } \\
\text { mouth disease. } \\
\text { 3. Taking snake meet keeps } \\
\text { away from evil spirits. }\end{array}$ & $\begin{array}{l}\text { Meat is believed to improve } \\
\text { eye sight \& facilitates } \\
\text { urination. Similar use in foot } \\
\text { and mouth disease of cattle } \\
\text { but tribes like Koya, } \\
\text { Guthikoya, Lambada, Mala of } \\
\text { Andhra Pradesh use skin } \\
\text { unlike raw meat in [59]. } \\
\text { Slough is used to decorate } \\
\text { the home and as well in } \\
\text { worship by Garasiya people of } \\
\text { Rajasthan [21]. }\end{array}$ \\
\hline
\end{tabular}


Table 1 Inventory of vertebrate species used for medicinal purposes by members of Nyishi (N) and Galo (G) tribes in Arunachal Pradesh (N E India) (Continued)

\begin{tabular}{|c|c|c|c|c|c|c|c|}
\hline 10 & $\begin{array}{l}\text { Monitor } \\
\text { lizard }\end{array}$ & $\begin{array}{l}\text { Horkek }(G) \\
\text { Baminsopin } \\
(\mathrm{N})\end{array}$ & $\begin{array}{l}\text { Varanus } \\
\text { bengalensis }\end{array}$ & $N \& G$ & Flesh & Cough, fever & $\begin{array}{l}\text { Flesh boiled and taken } \\
\text { whenever available as a } \\
\text { preventive measure for } \\
\text { coughs and fevers. }\end{array}$ \\
\hline
\end{tabular}

Meat promotes strength and vitality and fat used for joint pain by Koya, Guthikoya, Lambada, Mala tribes of Andhra Pradesh [59]. Skin and fat used for treating piles, rheumatism, body pain by Ao tribe of Nagaland [49]. Fat is used for massage to treat arthritis by Irular, Mudugar, Kurumber tribes of Western Ghat Kerala [60]. Cooked flesh is eaten by Garasiya people of Rajasthan to promote body stamina [21]. Oil is used for back pain [68]. Flesh is used to treat arthritis by tribals of Tamil Nadu [61].

\begin{tabular}{|c|c|c|c|c|c|c|c|c|}
\hline \multicolumn{9}{|c|}{ Birds } \\
\hline 11 & $\begin{array}{l}\text { Hornbills: } \\
\text { 1. Necked } \\
\text { 2. } \\
\text { Weathered } \\
\text { 3. Great } \\
\text { 4. Pied }\end{array}$ & $\begin{array}{l}\text { Poe, Paga } \\
(\mathrm{N}, \mathrm{G})\end{array}$ & $\begin{array}{l}\text { 1. Aceros } \\
\text { nipalensis, } \\
\text { 2. A. } \\
\text { undulatus } \\
\text { 3. Buceros } \\
\text { bicornis, } \\
\text { 4. } \\
\text { Anthracoceros } \\
\text { albirostris }\end{array}$ & $N \& G$ & Fats, & $\begin{array}{l}\text { Body massage } \\
\text { to ease body } \\
\text { pains }\end{array}$ & $\begin{array}{l}\text { Stored fats are commonly } \\
\text { used for massaging aching } \\
\text { body parts. }\end{array}$ & $\begin{array}{l}\text { Cooked flesh is used for the } \\
\text { treatment of rheumatic pain } \\
\text { by Irular, Mudugar, Kurumber } \\
\text { tribes of Western Ghat Kerala } \\
\text { [60]. }\end{array}$ \\
\hline 12 & Crow & $\begin{array}{l}\mathrm{Pa}(\mathrm{N}) \mathrm{Pak} \\
(\mathrm{G})\end{array}$ & $\begin{array}{l}\text { Corvus } \\
\text { splendens }\end{array}$ & $N \& G$ & Flesh & $\begin{array}{l}\text { Stomach } \\
\text { disorder }\end{array}$ & $\begin{array}{l}\text { Dried meat is taken to } \\
\text { minimize stomach upsets. } \\
\text { Meat fed to children improves } \\
\text { their intelligence. }\end{array}$ & $\begin{array}{l}\text { Flesh is used for treatment of } \\
\text { rheumatism, paralysis, earache } \\
\text { by Ao tribe of Nagaland [49]. } \\
\text { Fat is used to treat smallpox \& } \\
\text { malaria by Mompa tribe of } \\
\text { Arunachal Pradesh [27]. Meat } \\
\text { cooked in mustered oil is } \\
\text { used for leucoderma by Irular, } \\
\text { Mudugar, Kurumber tribes of } \\
\text { Western Ghat Kerla [60]. } \\
\text { Excreta are topically applied } \\
\text { to cure blisters by Garasiya } \\
\text { people of Rajasthan [21]. Flesh } \\
\text { is traditional medicine for } \\
\text { whooping cough by Kachch } \\
\text { of Gujrat [69] and anaemia in } \\
\text { tribals of Tamil Nadu [61]. }\end{array}$ \\
\hline 13 & Eagle & Kyokam (N) & $\begin{array}{l}\text { Spilornis } \\
\text { cheela }\end{array}$ & $\mathrm{N}$ & $\begin{array}{l}\text { Fat and } \\
\text { feathers }\end{array}$ & $\begin{array}{l}\text { Burns, wounds } \\
\text { body sprains }\end{array}$ & $\begin{array}{l}\text { Oil applied locally and } \\
\text { wounds covered by feathers. }\end{array}$ & $\begin{array}{l}\text { Fat is used to treat sprains \& } \\
\text { burns by Ao Nagas [49], but } \\
\text { malaria \& typhoid by } \\
\text { Arunachal Pradesh's Mompas } \\
\text { [27]. }\end{array}$ \\
\hline 14 & Owl & Puptal (G) & $\begin{array}{l}\text { Bubo } \\
\text { nipalensis B. } \\
\text { bubo }\end{array}$ & G & Flesh & $\begin{array}{l}\text { Maleness } \\
\text { (malevolency) }\end{array}$ & Smoked flesh is taken & $\begin{array}{l}\text { Owls are of importance in the } \\
\text { zootherapeutic treatments, } \\
\text { but the species differ in } \\
\text { different parts of the country. } \\
\text { Similar use: Meat of Strixaluca } \\
\text { nivicola (owl) promotes } \\
\text { strength \& vitality as used by } \\
\text { Koya, Guthikoya, Lambada, } \\
\text { Mala tribes of Andhra Pradesh } \\
\text { [59] and Shoka people of } \\
\text { Uttaranchal [70], but wings of } \\
\text { Otus bakkamoena burnt and } \\
\text { inhaled in order to reduce } \\
\text { stomachache by Garasiya of } \\
\text { Rajasthan [21]. }\end{array}$ \\
\hline
\end{tabular}


Table 1 Inventory of vertebrate species used for medicinal purposes by members of Nyishi (N) and Galo (G) tribes in Arunachal Pradesh (N E India) (Continued)

\begin{tabular}{|c|c|c|c|c|c|c|c|c|}
\hline \multicolumn{9}{|c|}{ Mammals } \\
\hline & 15 Mithun & $\begin{array}{l}\text { Sobo }(G) \\
\text { Sebe }(N)\end{array}$ & Bos frontalis & $N \& G$ & $\begin{array}{l}\text { Gall } \\
\text { bladder, } \\
\text { testicles. }\end{array}$ & $\begin{array}{l}\text { 1. Dysentery, } \\
\text { Coughs \& fever } \\
\text { 2. Lactation of } \\
\text { mother }\end{array}$ & $\begin{array}{l}\text { 1. Gall bladder is filled with } \\
\text { rice powder and tied properly } \\
\text { and smoked dry. A pinch of it } \\
\text { is cooked with rice and taken } \\
\text { until disease is cured. } \\
\text { 2. A pinch of smoked, dry } \\
\text { testes is cooked and fed twice } \\
\text { a day to a mother who is } \\
\text { secreting less milk than } \\
\text { expected after delivery. }\end{array}$ & $\begin{array}{l}\text { Penis is used to treat skin } \\
\text { disease, breast pain of } \\
\text { lactating mother by Ao tribe } \\
\text { of Nagaland [49]; also } \\
\text { reported from Arunachal } \\
\text { Pradesh [26]. }\end{array}$ \\
\hline 16 & Goat & Sabing (N) & Capra hircus & $N$ & $\begin{array}{l}\text { Gall } \\
\text { bladder \& } \\
\text { frontal } \\
\text { bone. }\end{array}$ & $\begin{array}{l}\text { Fever \& early } \\
\text { pregnancy pain, } \\
\text { stomach ache }\end{array}$ & $\begin{array}{l}\text { The frontal bone is burnt and } \\
\text { taken in pinches mixed with } \\
\text { boiled water } 2-3 \text { times a day } \\
\text { to minimize fever and early } \\
\text { pregnancy pain. Gall bladder } \\
\text { is cooked with rice and taken } \\
\text { for stomach ache. }\end{array}$ & $\begin{array}{l}\text { Meat is reported to stimulate } \\
\text { digestion among tribes like } \\
\text { Koya, Guthikoya, Lambada, } \\
\text { Mala of Andhra Pradesh [59]. } \\
\text { Soup of leg bone is used to } \\
\text { cure weakness; urine is used } \\
\text { for tuberculosis by Saharia } \\
\text { tribe of Rajasthan [67]. Urine } \\
\text { of Capra sibirica is used to } \\
\text { treat asthma by Ao tribe of } \\
\text { Nagaland [49]. }\end{array}$ \\
\hline 17 & Rat & Kojak (N) & Rattus sp. & $N$ & $\begin{array}{l}\text { Whole } \\
\text { body }\end{array}$ & $\begin{array}{l}\text { To minimize } \\
\text { pain after } \\
\text { conception }\end{array}$ & $\begin{array}{l}\text { Whole body is burnt and } \\
\text { crushed or powdered, taken } \\
\text { with rice as a painkiller after } \\
\text { conception (early pregnancy). }\end{array}$ & - \\
\hline 18 & Mole & Kor tab (N) & Talpa sp. & $\mathrm{N}$ & Flesh & Tuberculosis & $\begin{array}{l}\text { Flesh/Meat is cooked and } \\
\text { eaten in order to cure } \\
\text { tuberculosis. }\end{array}$ & $\begin{array}{l}\text { Flesh is used for asthma by } \\
\text { Ao tribe of Nagaland [49]. }\end{array}$ \\
\hline 19 & Fox & Siyali (N) & $\begin{array}{l}\text { Vulpes } \\
\text { bengalensis, } \\
\text { Canis aureus }\end{array}$ & $N$ & Flesh & Tuberculosis & $\begin{array}{l}\text { Meat is boiled or roasted and } \\
\text { taken. }\end{array}$ & $\begin{array}{l}\text { Fat is used for rheumatism, } \\
\text { skin disease by Irular, } \\
\text { Mudugar, Kurumber tribes of } \\
\text { Western Ghat Kerala [60]. }\end{array}$ \\
\hline 20 & Wolf & Sarchi (N) & Canis lupus & $N$ & Skin & $\begin{array}{l}\text { Coughs \& fevers, } \\
\text { epidemics }\end{array}$ & $\begin{array}{l}\text { Skin (whenever available) is } \\
\text { burnt and taken in pinches as } \\
\text { a preventive measure. }\end{array}$ & $\begin{array}{l}\text { Meat is used to cure asthma, } \\
\text { paralysis \& arthritis by Koya, } \\
\text { Guthikoya, Lambada, Mala of } \\
\text { Andhra Pradesh [59]. }\end{array}$ \\
\hline 21 & Porcupine & $\begin{array}{l}\text { Sihi (N) Hoi } \\
(G)\end{array}$ & Hystrix sp. & $N \& G$ & $\begin{array}{l}\text { Gall } \\
\text { bladder, } \\
\text { stomach } \\
\& \\
\text { intestines, } \\
\text { flesh }\end{array}$ & $\begin{array}{l}\text { Diarrhoea, } \\
\text { gastritis, } \\
\text { tuberculosis }\end{array}$ & $\begin{array}{l}\text { 1. Gall bladder, stomach and } \\
\text { intestines (whenever available) } \\
\text { are boiled and taken with rice } \\
\text { as a preventive measure for } \\
\text { diarrhoea and gastritis. 2. The } \\
\text { meat and stomach portions } \\
\text { are cooked and fed to a } \\
\text { person suffering from } \\
\text { tuberculosis. }\end{array}$ & $\begin{array}{l}\text { Similar use: Dried stomach \& } \\
\text { intestine used for digestive } \\
\text { disorders by Koya, Guthikoya, } \\
\text { Lambada, Mala of Andhra } \\
\text { Pradesh [59]; bile for } \\
\text { dysentery by Ao tribe of } \\
\text { Nagaland [49]; boiled flesh for } \\
\text { stomachache, piles, breathing } \\
\text { trouble by Irular, Mudugar, } \\
\text { Kurumber of Western Ghat } \\
\text { Kerala [60]; boiled gut content } \\
\text { is used to treat stomachache, } \\
\text { indigestion and coughs and } \\
\text { colds by tribals in Arunachal } \\
\text { Pradesh [26]. }\end{array}$ \\
\hline 22 & Pangolin & Hosik(G) & $\begin{array}{l}\text { Manis } \\
\text { pentadactyla }\end{array}$ & $G$ & Nails & Boils & $\begin{array}{l}\text { For piercing the boils } \\
\text { (assumed antiseptic property) }\end{array}$ & - \\
\hline 23 & Mongoose & $\begin{array}{l}\text { Sanf sakyo } \\
\text { (N) }\end{array}$ & $\begin{array}{l}\text { Herpestes } \\
\text { javanicus }\end{array}$ & $N$ & $\begin{array}{l}\text { Whole } \\
\text { body }\end{array}$ & $\begin{array}{l}\text { Preventive } \\
\text { measure for any } \\
\text { disease }\end{array}$ & $\begin{array}{l}\text { Roasted or boiled and taken } \\
\text { as a preventive measure to } \\
\text { avoid diseases. }\end{array}$ & $\begin{array}{l}\text { Properly cooked penis is used } \\
\text { to treat impotence by males } \\
\text { of Ao tribe in Nagaland [49]. }\end{array}$ \\
\hline
\end{tabular}


Table 1 Inventory of vertebrate species used for medicinal purposes by members of Nyishi (N) and Galo (G) tribes in Arunachal Pradesh (N E India) (Continued)

\begin{tabular}{|c|c|c|c|c|c|c|c|c|}
\hline 24 & Deer & $\begin{array}{l}\text { Hudum, } \\
\text { hocher (G) } \\
\text { Sudum (N) }\end{array}$ & $\begin{array}{l}\text { Moschus } \\
\text { chrysogaster, } \\
\text { M. moschiferus }\end{array}$ & $N \& G$ & $\begin{array}{l}\text { Gall } \\
\text { bladder, } \\
\text { fresh } \\
\text { blood } \\
\text { umbilicus }\end{array}$ & $\begin{array}{l}\text { Malaria, } \\
\text { diarrhoea, } \\
\text { Fevers, stomach } \\
\text { upset, body } \\
\text { immunity, } \\
\text { tuberculosis }\end{array}$ & $\begin{array}{l}\text { Rice is cooked with fresh gall } \\
\text { bladder and } 100-200 \mathrm{~g} \text { are } \\
\text { taken once a day till some } \\
\text { improvement is seen. A pinch } \\
\text { of smoke dried umbilicus is } \\
\text { mixed in } 1 / 2 \text { litre boiled water } \\
\text { and fed to the patient till } \\
\text { disease is cured (same } \\
\text { prescription for all indications). } \\
\text { Boiled blood is taken as food } \\
\text { and considered to improve } \\
\text { body immunity. }\end{array}$ & $\begin{array}{l}\text { Similar: Musk is used to cure } \\
\text { malaria, heart ailments and to } \\
\text { promote immunity to } \\
\text { lactating mothers by Koya, } \\
\text { Guthikoya, Lambada, Mala of } \\
\text { Andhra Pradesh [59]; malaria, } \\
\text { diarrhoea by Mompa of } \\
\text { Arunachal Pradesh [27]. }\end{array}$ \\
\hline 25 & $\begin{array}{l}\text { Sambar } \\
\text { deer }\end{array}$ & Hudum (G) & $\begin{array}{l}\text { Cervus } \\
\text { unicolor }\end{array}$ & G & Horn & $\begin{array}{l}\text { Bursting open } \\
\text { boils }\end{array}$ & $\begin{array}{l}\text { Crushed horn particles added } \\
\text { with very little salt and are } \\
\text { used for bursting off boils. }\end{array}$ & $\begin{array}{l}\text { Fat: massaged in cases of } \\
\text { asthma \& rheumatism by } \\
\text { Irular, Mudugar, Kurumber } \\
\text { tribes of Western Ghat Kerala } \\
\text { [60]. Paste of antler to treat } \\
\text { herpes by Saharia tribe of } \\
\text { Rajasthan [67], the same } \\
\text { prescription applied directly } \\
\text { on the stomach by Garasiya } \\
\text { people of Rajasthan for } \\
\text { treatment of stomach ache } \\
\text { [21]. Penis is used to treat } \\
\text { hydroceles by tribal } \\
\text { population of Tamil Nadu [61]. }\end{array}$ \\
\hline 26 & $\begin{array}{l}\text { Moon } \\
\text { bear Black } \\
\text { bear }\end{array}$ & $\begin{array}{l}\text { Hutum (G) } \\
\text { Sutum (N) }\end{array}$ & $\begin{array}{l}\text { Ursus } \\
\text { thibetanus, } \\
\text { Selenarctos } \\
\text { thibetanus }\end{array}$ & $N \& G$ & $\begin{array}{l}\text { Gall } \\
\text { bladder }\end{array}$ & $\begin{array}{l}\text { Malaria, } \\
\text { diarrhoea, fever, } \\
\text { stomach upsets, } \\
\text { other common } \\
\text { diseases, body } \\
\text { immunity. }\end{array}$ & $\begin{array}{l}\text { The bladder is filled with rice } \\
\text { powder and smoke dried; a } \\
\text { pinch is either mixed with rice } \\
\text { or taken directly once a day, } \\
\text { till the disease gets } \\
\text { minimized. Dosage is same } \\
\text { for all. }\end{array}$ & $\begin{array}{l}\text { Similarly: Gall bladder of } \\
\text { Selenarctos thibetanus is used } \\
\text { for treatment of malaria, } \\
\text { typhoid and other serious } \\
\text { fevers by Mompa of } \\
\text { Arunachal Pradesh [27]; same } \\
\text { prescription to treat stomach } \\
\text { ache and diarrhoea, in } \\
\text { Arunachal Pradesh [26] and } \\
\text { bile of Selenarctos is used to } \\
\text { cure malaria by Ao Nagas [49]. }\end{array}$ \\
\hline 27 & Tiger & Pate (N) & Panthera tigris & $\mathrm{N}$ & $\begin{array}{l}\text { Bone and } \\
\text { marrow }\end{array}$ & Jaundice & $\begin{array}{l}\text { Cooked into soup and fed to } \\
\text { the patient. }\end{array}$ & $\begin{array}{l}\text { Dried bones are used for } \\
\text { treating rheumatic and other } \\
\text { body pain by Mompa of } \\
\text { Arunachal Pradesh [27]. Flesh } \\
\text { and fat are used for treatment } \\
\text { of leprosy by tribal population } \\
\text { of Tamil Nadu [61]. }\end{array}$ \\
\hline 28 & $\begin{array}{l}\text { Clouded } \\
\text { leopard } \\
\text { Common } \\
\text { leopard }\end{array}$ & Hogya (N) & $\begin{array}{l}\text { Neofelis } \\
\text { nebulosa, } \\
\text { Panthera } \\
\text { pardus }\end{array}$ & $\mathrm{N}$ & $\begin{array}{l}\text { Bone } \\
\text { marrow }\end{array}$ & Body pains & $\begin{array}{l}\text { Bone marrows are preserved } \\
\text { in bamboo cups and used for } \\
\text { body massaging }\end{array}$ & $\begin{array}{l}\text { Fat is used as massage for } \\
\text { body pain by Koya, Guthikoya, } \\
\text { Lambada, Mala tribes of } \\
\text { Andhra Pradesh [59] instead } \\
\text { of bone marrow. Flesh is used } \\
\text { for treating typhoid, malaria, } \\
\text { rheumatic pain by Mompa of } \\
\text { Arunachal Pradesh [27]. }\end{array}$ \\
\hline
\end{tabular}

\section{Preparation and administration}

Although distinct preparation and administration methods of the zootherapeutic resources existed (Table 1), some generalities were also noticed. For example, the fats of very different animal species like python, hornbill and eagle, to name but a few, is always heated up and then externally applied to relieve pain. Body parts of most species are either cooked, crushed into powder or boiled and then eaten. The use of flesh is common and usually taken in cooked or smoked form. Gall bladders and their contents seem another important raw material for members of both tribes. Beyond the uses for treating human diseases, zootherapeutic resources are also employed in ethno-veterinary medicines, e.g., for the treatment of foot and mouth disease in cattle. Barboza et. al. [54] even described zootherapeutic uses in connection with treatments of wild animals. 
The relatively large number of medicinally important vertebrate species catalogued, demonstrates the importance of zootherapeutic practices as an alternative to newly introduced western medicines amongst the Nyishi and Galo tribes. Of the 36 identified medicinal animal species, many are also, at least occasionally, used as food. This high percentage of animal species with such twin function as food and medicine is not surprising, given the important role that wildlife as a source of protein plays for the local inhabitants. Similar cases, in which food animals were also used in remedies, were reported from other parts of the world [18]. Our knowledge of the criteria used by the tribals to decide whether a species is primarily to be used as food or as part of therapies, however, is limited as a variety of tribal dietary taboos can obscure the information volunteered by an informant [55-57].

The use of animals for therapeutic purposes not only in remote but certain urban areas as well (often those occupied by the economically disadvantaged), suggests that zootherapeutic practices may function as a social conduit, aiding ethnic identity and cohesion amongst members of the Nyishi and Galo tribes. However, as elsewhere observed with regard to indigenous peoples and their traditional food systems [58], we also noticed that younger members of both tribes were more and more inclined to accept modern over traditional medicines.

\section{Inter-tribal comparisons}

Our study revealed a difference between Nyishi and Galo people in the use of vertebrates for medicinal purposes (Figure 7). Nyishis use more often mammalian species than Galo do. Generally speaking, selectivity is a very complex issue, which brings several aspects into consideration when one compares the two tribes, e.g., differences in the availability of the animal-derived product(s), differences in motivation to go and obtain the product(s) in question, environmental factors like climatic and geographic differences, different agricultural practices and traditions, and differences in the prevalent disease spectrum. For the moment, therefore, we are unable to state anything more other than that differences between neighbouring tribes regarding species considered therapeutically valuable, would spread the pressure on the resource across several species, rather than focusing it on one alone. The same conclusion was reached by Meyer-Rochow [57] for situations, in which one species, but not another, was considered taboo by one tribe, but the same species, but not the other, was considered perfectly acceptable by a neighbouring tribe.

Some of the animal species used therapeutically by Nyishis and Galos are also used in very similar ways by a number of other ethnic groups in India. The porcupine, for example, supplies Nyishis and Galos with flesh that is used to treat individuals suffering from tuberculosis. The porcupine is also used by tribes of Andhra Pradesh, Kerala, and Nagaland to remedy upsets of the digestive system, but the specific raw materials from this very same animal differ: in Andhra Pradesh one uses the dried stomach [59], Kerala tribes boil the flesh and consume it [60] and Ao Nagas use the intestine, gallbladder and bile [49]. Members of the Ao Naga and the Mompa of Arunachal Pradesh also use the bile and gallbladder of a bear, but not just for digestive disorders, but also for fighting malaria attacks $[27,49]$.

Musk deer flesh is used for enhancing body immunity and resistance to malaria by the Koya and Lambada tribes of Andhra Pradesh, the Ao Naga of Nagaland, and the Mompa of Arunachal Pradesh [27,59]. Amongst the tribes of Kerala hornbill fat is used to relieve body pain, but Nyishis and Galos use the bird's cooked flesh specifically to ease rheumatic pain [60]. Frogs (Rana spp.) are used by members of Nagaland and Kerala tribes to speed up wound healing, either through the consumption of whole frog bodies, the amphibian's flesh, or its skin alone $[49,60]$. The fat of the python also plays a role in the treatment of body pains or rheumatism amongst the tribes of Kerala [60], but peoples of Andhra Pradesh and members of the Nyishi and Galo use snakes in treating cattle that suffer from foot and mouth disease [59].

Depending on the region of India, some animals and their products can be put to very different uses. For example, the flesh of various species of monitor lizard is in use for treating humans suffering from coughs and fever by the Nyishi and Galo, but tribes of Andhra Pradesh, Kerala, and the Ao Naga of Nagaland use the same material to improve the overall vitality of a person and the fat of this reptile to treat rheumatism and pains of the joints $[49,59,60]$. The flesh of the crow is used in connection with stomach disorders by the Nyishi and Galo, but the same material is used in connection with rheumatism and paralysis by the Ao Naga [49] and with leucoderma by the tribes of Kerala [60].

The Mompa of Arunachal use the fat of the crow in cases of smallpox and malaria [27]. Members of the Nyishi and Galo tribes use the gall bladder of the mithun (Bos frontalis) in potions to stop dysentery, cough, and fever and prescribe the bull's testes to ease lactation problems of young mothers. Amongst the Ao Naga of Nagaland it is the bull's penis that is used for skin disorders and chest pain of lactating mothers [49]. The flesh of the fox, given to Nyishi and Galo children, is supposed to turn the children into cunning adults, but the flesh is also used as a tuberculosis remedy amongst the Nyishi. Tribes of Kerala employ the fox' fat in treatments of rheumatism and skin diseases [60]. Rather similarly, a wolf's burnt skin is taken to avoid 
Table 2 Present conservation status of animals mentioned in Table 1 and the paper (according to IUCN 2010 Red list of Threatened Species Version 2010.4)

\begin{tabular}{|c|c|c|}
\hline Species & Status & Remarks \\
\hline Pisces: & Least Concern Ver 3.1 & \\
\hline \multicolumn{3}{|l|}{$\begin{array}{c}\text { Anguilla bengalensis (Gray, 1831)[Synonym: } \\
\text { Muraena bengalensis Gray, 1831] }\end{array}$} \\
\hline Semiplotus sp. & Data Deficient Ver 3.1 & $\begin{array}{l}\text { The specimen was not identified up to species level. In the place four } \\
\text { species has been recorded Semiplotus cirrhosus, S. manipurensis, S. } \\
\text { modestus (Burmese Kingfish) and Cyprinion semiplotum (Assamese Kingfish) } \\
\text { [Synonym: Cyprinus semiplotus]. The present status for all except C. } \\
\text { semiplotum is data deficient, Ver 3.1; for C. semiplotum Vulnerable, Ver } 3.1\end{array}$ \\
\hline Labeo rohita (Hamilton, 1822) & Least Concern Ver 3.1 & \\
\hline Bagarius bagarius (Hamilton. 1822) & $\begin{array}{c}\text { Near Threatened Ver } \\
3.1\end{array}$ & \\
\hline Amblyceps sp. & - & The specimen could not be identified to species level \\
\hline Psilorhynchus balitora Hamilton 1822 & - & \\
\hline $\begin{array}{l}\text { Amphibia: } \\
\text { Hoplobatrachus tigrinus (Daudin, 1802) } \\
\text { [Synonym: Rana tigrina Daudin, 1802] }\end{array}$ & Least Concern Ver 3.1 & \\
\hline
\end{tabular}

\begin{tabular}{|c|c|c|}
\hline $\begin{array}{c}\text { Reptilia: } \\
\text { Python molurus (Linnaeus, 1758) } \\
\end{array}$ & $\begin{array}{l}\text { Lower Risk/Near } \\
\text { Threatened Ver } 3.2 \\
\end{array}$ & \\
\hline Naja sp. & (n) & $\begin{array}{c}\text { The specimen was not identified to species level. However two species of } \\
\text { Naja have been reported, Naja kaouthia (Monocled cobra) and Naja } \\
\text { oxiana (Central Asian Cobra). For N. kaouthia the present status is Least } \\
\text { Concern Ver } 3.1 \text { and for N. oxiana it is Data Deficient Ver } 3.1\end{array}$ \\
\hline Varanus bengalensis (Daudin, 1802) & Least Concern Ver 3.1 & \\
\hline $\begin{array}{c}\text { Aves: } \\
\text { Aceros nipalensis (Hodsgon, 1829) } \\
\end{array}$ & $\begin{array}{l}\text { Vulnerable A2cd+3cd } \\
\quad+4 c d \text { Ver } 3.1\end{array}$ & \\
\hline Aceros undulatus (Shaw, 1811) & Least Concern Ver 3.1 & \\
\hline Buceros bicornis (Linnaeus, 1758) & $\begin{array}{l}\text { Near Threatened Ver } \\
3.1 \\
\end{array}$ & \\
\hline Anthracoceros albirostris (Shaw \& Nodder, 1807) & Least Concern Ver 3.1 & \\
\hline Corvus splendens (Vieillot, 1817) & Least Concern Ver 3.1 & \\
\hline Spilornis cheela (Latham, 1790) & Least Concern Ver 3.1 & \\
\hline Bubo nipalensis (Hodgson, 1836) & Least Concern Ver 3.1 & \\
\hline Bubo bubo (Linnaeus, 1758) & Least concern Ver 3.1 & \\
\hline \multicolumn{3}{|l|}{$\begin{array}{l}\text { Mammalia: } \\
\text { Bos frontalis }\end{array}$} \\
\hline Capra hircus (Linnaeus, 1758) & - & \\
\hline Rattus rattus (Linnaeus, 1758) & Least Concern Ver 3.1 & \\
\hline Talpa sp & Least Concern Ver 3.1 & \\
\hline Vulpes bengalensis (Shaw, 1800) & Least Concern Ver 3.1 & \\
\hline Canis aureus (Linnaeus, 1758) & Least Concern Ver 3.1 & \\
\hline Canis lupus (Linnaeus, 1758) & Least Concern Ver 3.1 & \\
\hline Hystrix $s p$ & - & The specimen was not identified to species level. \\
\hline Manis pentadactyla (Linnaeus, 1758) & $\begin{array}{c}\text { Endangered A2d+3d } \\
+4 \mathrm{~d} \text { Ver } 3.1\end{array}$ & \\
\hline $\begin{array}{c}\text { Herpestes javanicus (E. Geoffroy Saint- Hilaire, } \\
\text { 1818) [Synonym: Herpestes palustris Ghose, } \\
\text { 1965] }\end{array}$ & Least Concern Ver 3.1 & \\
\hline $\begin{array}{l}\text { Moschus chrysogaster (Hodgson, 1839) } \\
\text { [Synonym: Moschus sifanicus Buchner, 1891] }\end{array}$ & $\begin{array}{l}\text { Endangered A2cd Ver } \\
3.1\end{array}$ & \\
\hline $\begin{array}{l}\text { Moschus moschiferus (Linnaeus, 1758) } \\
\text { [Synonym: Moschus sibiricus Pallas, 1779] }\end{array}$ & $\begin{array}{l}\text { Vulnerable A2d }+3 d+ \\
4 d \text { Ver } 3.1\end{array}$ & \\
\hline
\end{tabular}


Table 2 Present conservation status of animals mentioned in Table 1 and the paper (according to IUCN 2010 Red list of Threatened Species Version 2010.4) (Continued)

\begin{tabular}{cc}
\hline $\begin{array}{c}\text { Rusa unicolor (Kerr, 1792) [Synonym: Cervus } \\
\text { unicolor Kerr, 1792] }\end{array}$ & $\begin{array}{c}\text { Vulnerable A2cd+3cd } \\
+4 c d \text { Ver 3.1 }\end{array}$ \\
\hline $\begin{array}{c}\text { Ursus thibetanus (G. [Baron] Cuvier, 1823) } \\
\text { [Synonym: Selenarctos thibetanus] }\end{array}$ & $\begin{array}{c}\text { Vulnerable A2cd+3d+ } \\
4 \mathrm{~d} \text { Ver 3.1 }\end{array}$ \\
\hline Selenarctos thibetanus & \\
\hline Panthera tigris (Linnaeus, 1758) & $\begin{array}{c}\text { Endangered A2bcd+ } \\
\text { 4bcd+ C1+ 2a(i)Ver } \\
3.1\end{array}$ \\
\hline Neofelis nebulosa (Griffith, 1821) & $\begin{array}{c}\text { Vulnerable C1+ 2a(i) } \\
\text { Ver 3.1 }\end{array}$ \\
\hline Panthera pardus (Linnaeus, 1758) & Near Threatened Ver \\
\end{tabular}

attacks of cough or fever by the Nyishi, but the wolf's meat is used for alleviating asthma attacks, paralysis, and arthritis by the tribes of Andhra Pradesh [59]. An entire mongoose, eaten roasted or boiled, is said by Arunachal tribes to serve as a preventive measure of any disease, but its penis alone is used to treat impotence amongst the Ao Naga [49]. Crushed antlers of the sambar deer are used by the Galo for bursting open boils and the deer's fat is used as an asthma and rheumatism remedy by Kerala tribes [60]. Tiger bone is used for jaundice by the Nyishi, but according to members of the Mompa tribe dried tiger bone powder is said to ease rheumatic pains [27], while tiger flesh and fats are used for treatments of leprosy by tribal people of Tamil Nadu [61].

The use of hornbill species, thought by members of the Nyishi and Galo tribes to speed up healing processes, has not been reported earlier in India, although hornbills are regarded as medicinal by members of the Irular, Mudugar and Kurumbar tribes of the Western Ghats of Kerala [60]. Except for the Ao Naga of Nagaland [49] and the Nyishi and Galo of Arunachal Pradesh the use of the mithun (Bos frontalis) in traditional remedies has also not been reported from any other tribe in India as were the therapeutic uses of some freshwater fishes like, Bagarius bagarius and Amblyceps sp., the rodent Rattus sp., and the pangolin Manis pentadactyla. One reason could be the unavailability of certain species in a particular region; another would be lack of appropriate ethnobiological and ethnomedical field data.

\section{Zootherapies: impacts on society and environment}

It is widely accepted that the use of certain plants and animals and their products in folk or traditional medicines indicates the presence of biologically active constituents in them. Although considerable information is available on phytochemistry and/or phytopharmacology of many traditional medicinal plants, bio-scientific evaluations of animal remedies are still quite rare [62]. Yet, some of the animals that are therapeutically used by traditional healers have been methodically tested by pharmaceutical companies and were, indeed, found to contain substances useful for the manufacture of drugs used in modern medicine [63].

The zoo-therapeutic knowledge, especially that of the Nyishi and Galo, was found to be based on few domestic and several wild animals, but some of the latter, serving as important folk medicinal resources like the hornbill, pangolin, clouded leopard, tiger, bear etc, are rare and protected species - a fact that is of considerable concern. Since Nyishis and Galos as well as other tribes have been using these animals for a long time, suppression to use them is not likely to save them from extinction. Rather it will be better to develop a conservation strategy, which is applicable to a particular locality giving the utmost respect to the ethnic sentiment and social structure of the locals. In accordance with Kunin and Lawton [63], those species directly involved in traditional medicines should be amongst those of the highest priority for conservation. According to Costa-Neto [33] research on zootherapies should be compatible with the welfare of the medicinal animal species, and the use of their by-products should be done in a sustainable manner. The species could be conserved through the integrated approach of in-situ and ex-situ conservation.

The establishment of a "Village Traditional Knowledge Bank" could be one of the significant approaches to not only conserve the diversity and related knowledge, but also to contribute in assuring quality of the livelihood of the ethnic people of Arunachal Pradesh in a broader sense and that of the Galo and Nyishi tribes in particular. The traditional medicines and the animal products used in the therapies should be tested for their effectiveness and chemical components; local folk should be made aware of the protected and endangered animal species and their importance as a resource for traditional medicines as well as for the region's tourist potential and biodiversity. Searching out or identifying 


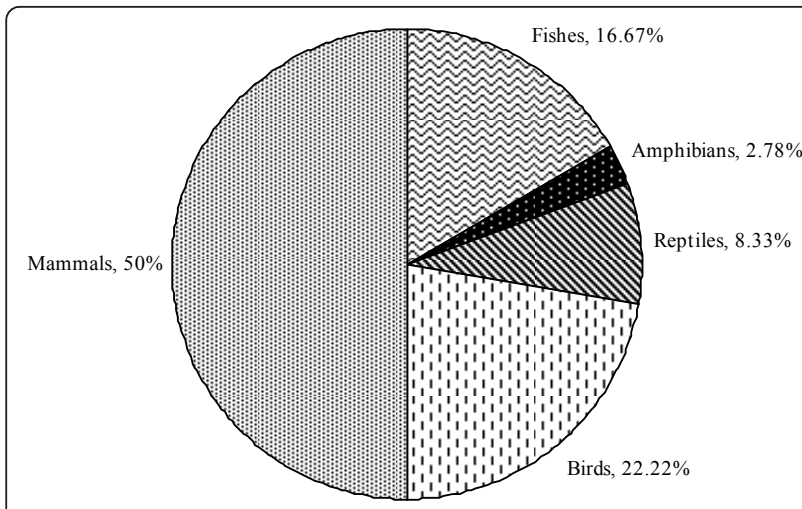

Figure 4 Percentages of species in different vertebrate classes reported for medicinal use by Nyishi and Galo tribes of Arunachal Pradesh.

substitutes for the medicinally used animal species should accompany the efforts of conservations. As has been suggested earlier $[64,65]$ botanical alternatives to the use of the threatened animals should be considered. Moreover, it might be possible to replace the currently medicinally-used wild species with domesticated animals and their products, provided one can demonstrate similar therapeutic effects of the latter to the former. Thus, economic as well as ecological aspects need to be addressed [66].

\section{Conclusion}

The main reasons for the popularity of zootherapies seem to be: a) economic and geographic accessibilities of animals assumed to possess therapeutic properties; b) the treatment's perceived efficacy; and c) socio-cultural factors like traditions, peer-pressure, cost of treatment, etc. Because Arunachal Pradesh is highly heterogeneous socially and profoundly unequal in the distribution of wealth and education, socioeconomic aspects clearly play a role in the persistence of zootherapeutic practices. Yet, the inclination of the younger generation towards

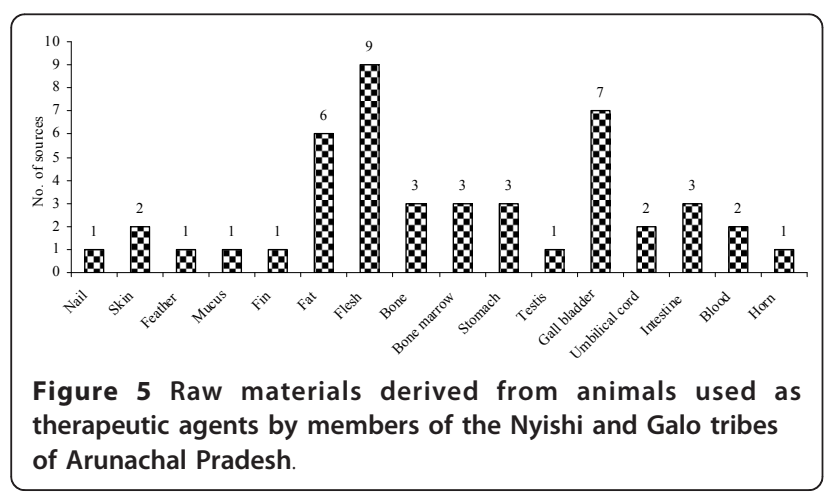

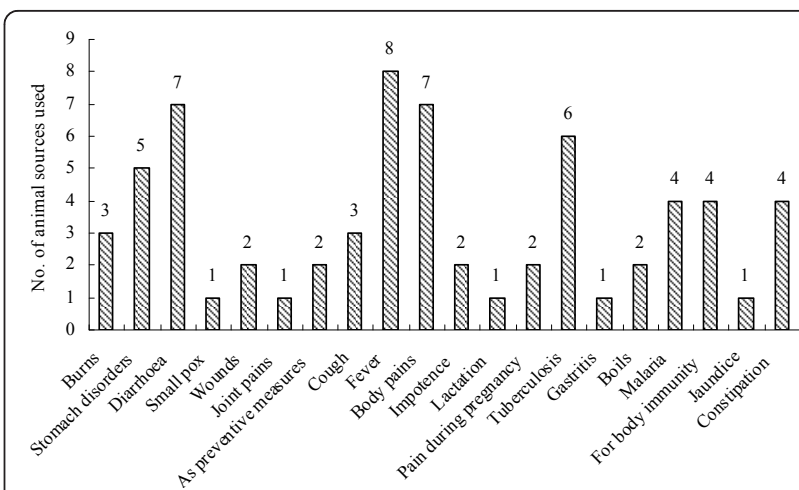

Figure 6 Number of medicinal uses reported in connection with different indications amongst members of the Nyishi and Galo tribes of Arunachal Pradesh.

welcoming and accepting modern medicine, while neglecting their own traditional body of knowledge with regard to the multitude of zootherapeutic uses, has cast considerable concerns on cleanliness, appropriateness, and effectiveness of the zootherapeutic products.

Hygienic conditions of zootherapeutically employed products are, indeed, generally poor and there is a need for sanitary testing and monitoring of animal-derived medicinal products. Additionally, chemical and pharmacological and perhaps epidemiological studies are necessary to clarify the eventual therapeutic usefulness of this class of biological remedies. Investigations of this kind would facilitate decisions on whether or not certain zootherapies could be accepted into public health programs. Finally, research into the abundance and availability of those particular animal species that are primarily used in the local therapies would be important in safeguarding them as a resource and, at the same time, in assuring their continued presence within the biodiversity of the region.

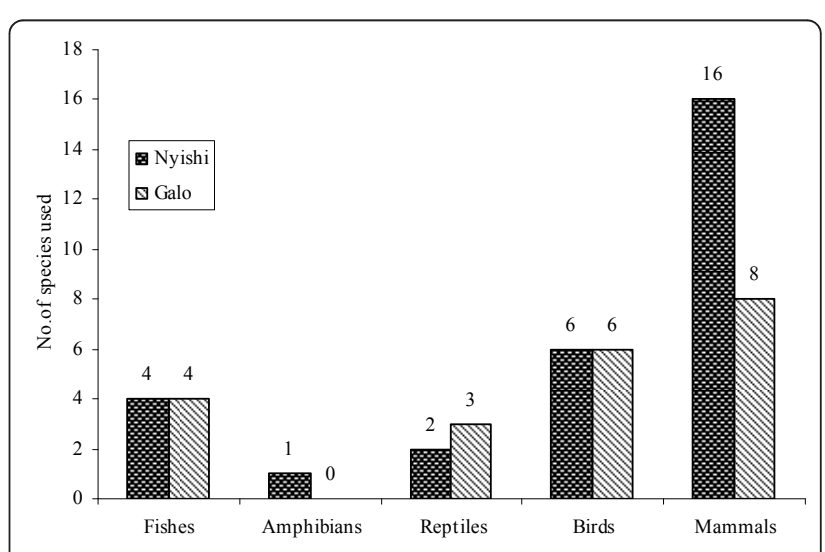

Figure 7 Numbers of species in different vertebrate classes used for medicinal purposes by Nyishi and Galo tribes of Arunachal Pradesh. 


\section{Acknowledgements}

The authors are thankful to the University Grants Commission, New Delhi for the financial support through a DBT, New Delhi, Associateship to Dr Chakravorty. Thanks are also due to Rajiv Gandhi University, Arunachal Pradesh, India, and Jacobs University Bremen, Germany, for providing facilities. The authors are also grateful to all the respondents, who shared their traditional zootherapeutic knowledge with us. Without their contribution this study would have been impossible.

\section{Author details}

'Biochemical Nutrition Laboratory, Dept. of Zoology, Rajiv Gandhi University, Arunachal Pradesh 791112, India. ${ }^{2}$ School of Engineering and Science, Jacobs University, Research II (Rm. 37) D-28759 Bremen, Germany.

\section{Authors' contributions}

JC carried out the field work and supervised SG's research. SG participated in the field work and identification of the insects. VBM-R began his ethnobiological studies in North-East India in 1991 and participated in the design, coordination, and draughting of the final manuscript. All authors read and approved the final manuscript.

\section{Competing interests}

The authors declare that they have no competing interests.

Received: 24 January 2011 Accepted: 31 March 2011

Published: 31 March 2011

\section{References}

1. Chivian E: Global environmental degradation and biodiversity loss: Implications for human health. In Biodiversity and human health.. 1 edition. Edited by: Grifo F, Rosenthal J. Washington DC, Island Press; 1997:7-38.

2. Springer MS, Murphy WJ: Mammalian evolution and biomedicine: new views from phylogeny. Biol Rev 2007, 82:375-392.

3. Rolston $\mathrm{H}$ : The land ethics at the turn of the millennium. Biodiversity and Conservation 2000, 9:1045-1058

4. Chardonnet P, Des Clers B, Fischer J, Gerhold R, Jori F, Lamarque F: The value of wildlife. Revue Scientifique 2002, 21:15-51.

5. Saito Y: Ecological designs: promises and challenges. Environmental Ethics 2002, 24:243-261.

6. Alves RRN, Rosa IL: Why study the use of animal products in traditional medicine? J Ethnobiol Ethnomed 2005, 1:5

7. Marques JGW: Fauna medicinal: Recurso do ambiente ou ameaca a biodiversidade? Mutum 1997, 1:4.

8. WEHAB: A frame work for action on biodiversity and ecosystem Management. The WEHAB working group; 2002 [http://www.iisd.ca/wssd/ download\%20files/wehab_biodiversity.pdf].

9. Phillipson JD, Anderson LA: Ethnopharmacology and western medicine. J Ethnopharmacol 1989, 25(1):61-72.

10. WHO/IUCN/MWF: Guidelines on conservation of medicinal plants Gland, Switzerland, Castle Cary Press; 1993

11. Lev E: Traditional healing with animals (zootherapy): medieval to present day Leventine practice. J Ethnopharmacol 2003, 86:107-118.

12. Costa-Neto EM, Marques JGW: Faunistic resources used as medicines by artisanal fishermen from Siribinha Beach, State of Bahia. Brazil J Ethnobiol 2000, 20:93-109.

13. China National Corporation of Traditional and Herbal Medicine: Materia medica commonly used in China Beijing, Science Press; 1995.

14. Reid BE: Chinese materia medica: insect drugs, dragon and snake drugs. In Chinese Medicine Series. Volume 2. Taipei, Materials Center Inc; 1982.

15. Schimitschek E: Insekten als Nahrung, in Brauchtum, Kult und Kultur. In Handbuch der Zoologie - eine Naturgeschichte der Stämme des Tierreichs, Band Vier. Edited by: Helmcke J-G, Stark D, Wermuth H. Berlin, Akademie Verlag; 1968:1-62.

16. Lohani U: Man-animal relationships in central Nepal. J Ethnobiol Ethnomed 2010, 6:31.

17. Ali SAM, Mahdihassan S: Bazaar medicines of Karachi: The drugs of animal origin. In Bazaar Drugs and Folk Medicine in Pakistan. Edited by: Mahdihassan, S. Karachi, Hamdard Publ; 1984:69-73.

18. Alves RRN: Fauna used in popular medicine in Northeast Brazil. $J$ Ethnobiol Ethnomed 2009, 5:1.
19. Alves RRN, Vieira WLS, Santana GG: Reptiles used in traditional folk medicine: conservation implications. Biodiversity and Conservation 2008 , 17(1):2037-2049.

20. Mahawar MM, Jaroli DP: Traditional zootherapeutic studies in India: A review. J Ethnobiol Ethnomed 2008, 4:17.

21. Jaroli DP, Mahawar MM, Vyas N: An ethnozoological study in the adjoining areas of Mount Abu wildlife sanctuary, India. J Ethnobiol Ethnomed 2010, 6:6.

22. Shah KB, Gire MK: Some amphibians and their local uses in Arun Basin. J Nat Hist Museum 1992, 13:9-17.

23. Solavan A, Paulmurunguan R, Wilsanand V, Ranjith Sing AJA: Traditional therapeutic uses of animals among tribal population of Tamil Nadu. Ind J Trad Knowledge 2004, 3(2):198-204.

24. Deb AK, Haque CE: Every mother is a mini-doctor: Ethnomedicinal uses of fish, shellfish and some other aquatic animals in Bangladesh. J Ethnopharmacol 2011, 134(2):259-267.

25. Mishra N, Rout SD, Panda T: Ethno-zoological studies and medicinal value of Similipal Biosphere, Orissa, India. Afr J Pharmacy Pharmacol 2011, 5(1):6-11.

26. Borang A: Use of certain animals and animal products in indigenous system of treatment in Arunachal Pradesh. In Ethonomedicine of tribes of Arunachal Pradesh. Edited by: Mibang T, Choudhury SK. New Delhi, Himalayan Publisher; 2003:18-23.

27. Solanki GS, Chutia P: Ethnozoological and socio- cultural aspects of Mompas of Arunachal Pradesh. J Human Ecol 2004, 15(4):251-254

28. Launet E: Dans les forêts, à la recherche des médicaments de demain. Science et Vie 1993, 904:86-91.

29. Amato I: From 'hunter magic' a pharmacopeia? Science 1992, 258:1306

30. Fink M: Convulsive therapy: a review of the first 55 years. J Affective Disorders 2001, 63:1-15.

31. Kang SK, Kim KS, Kim SI, Chung KH, Lee IS, Kim CH: Immunosuppressive activity of deer antler extracts of Cervus korea Temminck, var. mantchuricus Swinhoe, on type II collagen-induced arthritis. In-vitro Cellular and Developmental Biology (Animal) 2006, 42:100-107.

32. Moreau M, Dupuis J, Bonneau NH, Lécuyer M: Clinical evaluation of a powder of quality elk velvet antler for the treatment of osteoarthrosis in dogs. Can Vet J 2004, 45:133-139.

33. Costa-Neto EM: Animal based medicines: biological prospection and the sustainable use of zootherapeutic resources. Annals Brazil Acad Sci 2005, 77(1):33-43.

34. Chakravorty J, Ghosh S, Meyer-Rochow VB: Practices of entomophagy and entomotherapy by members of the Nyishi and Galo tribes of the state of Arunachal Pradesh (North-East India). J Ethnobiol Ethnomed 2011, 7:5.

35. The Director: Fauna of Arunachal Pradesh, Part 1-State fauna series 13 Kolkata, Zoological Survey of India; 2006

36. Grewal B, Pfister O: A photographic guide to birds of the Himalayas London, New Holland Publ Ltd; 2004.

37. Alfred JRB, Sinha NK, Chakravorty S: Checklist of mammals of India (Occasional paper No. 199) Kolkata, Zoological Survey of India; 2002.

38. Ahmed MF, Das A, Dutta SK: Amphibians and reptiles of Northeast India Guwahati, Aranyak; 2009.

39. Mathew R, Sen N: Pictorial guide of amphibians of North East India Kolkata, Zoological Survey of India; 2010.

40. Sharma VP: The relevance of traditional animal drugs of bird origin used by Bhil tribal of Rajasthan state, India. Geobios News Reports 1987, 6:129-132.

41. Rosner F: Pigeon as a remedy (segulah) for jaundice. N Y State J Med 1992, 92(5):189-192.

42. Marques JGW: A fauna medicinal dos indios Kuna de San Blas (Panama) e a hipotese da universaliodae zooterapica. Proc. 46th Annual Meet Brazil Soc Progr Sci Victoria, Brazil, Espirito Santo Federal University; 1994.

43. Sharma VP, Khan AU: Drugs of mammals origin used by aborigines of Garo hills of Meghalaya State, India. Bionature 1995, 15(1):1-55.

44. Sodeinde OA, Soewu DA: Pilot study of the traditional medicine trade in Nigeria. Traffic Bull 1999, 18(1):35-40.

45. El-Kamali HH: Folk medicinal use of some animal products in Central Sudan. J Ethnopharmacol 2000, 72:279-282.

46. Aldasoro EM, Heliot Z: Animals with magical and medicinal uses in markets of the state of Mexico. Proc 25th Annual Conference of the Society of Ethnobiology, Art and Soul: Celebrating Indigenous Artisans Storrs, Connecticut University of Connecticut; 2002. 
47. Vazquez PE, Mendez RM, Guiascon OGR, Pinera EJN: Uso medicinal de la fauna silvestre en los Altos de Chiapas, Mexico. Interciencia 2006, 31(7):491-499.

48. Kakati LN, Doulo V: Indigenous knowledge system of zootherapeutic use by Chakhesang tribe of Nagaland, India. J Human Ecol 2002, 13(6):419-423.

49. Kakati LN, Ao B, Doulo V: Indigenous knowledge of zootherapeutic use of vertebrate origin by the Ao Tribe of Nagaland. J Human Ecol 2006, 19(3):163-167.

50. Camargo M: Garrafada Rio de Janeiro, Ministerio da Educacao e Cultura; 1975.

51. Alves RRN, Rosa IL, Santana GG: The role of animal-derived remedies as complementary medicine in Brazil. BioScience 2007, 57(11):949-955.

52. Changkija S, Ajungla L, Rongsensashi, Renchumi-Mozhwui : Medicinal and aromatic flora of Nagaland Kohima, Nagaland Government Publ; 2010.

53. Ahmed M, Dutta DN, Borthakur SK, Gogoi P: National seminar on commercial cultivation of medicinal plants in Northeat India Guwahati, NE Development Finance Corp Ltd; 2010, 1-219.

54. Barboza RRD, Souto Wde MS, Mourão J, da S: The use of zootherapeutics in folk veterinary medicine in the district of Cubati, Paraiba State, Brazil. J Ethnobiol Ethnomed 2007, 3:32.

55. Begossi A: Food taboos - a scientific reason? In Plants for food and medicine. Edited by: Pendergast HDV, Etkin N, Harris DR, Houghton PJ. Kew, UK, Royal Botanic Gardens; 1998:41-461.

56. Trigo M, Roncada MJ, Stewien GT, Pereira IM: Food taboos in northern Brazil. Revista de Saude Publica 1989, 6:455-464.

57. Meyer-Rochow VB: Food taboos: their origins and purposes. J Ethnobiol Ethnomed 2009, 5:18.

58. Kuhnlein HV, Receveur : Dietary change and traditional food systems of indigenous peoples. Ann Rev Nutrition 1996, 16:417-442.

59. Benarjee G, Srikanth $K$, Ramu G, Ramulua KN: Ethnozoological study in a tropical wildlife sanctuary of Eturunagaram in the Warangal district, Andhra Pradesh. Ind J Trad Knowledge 2010, 9:701-704.

60. Padmanabham P, Sujana KA: Animal products in traditional medicine from Attappady Hills of Western Ghats. Ind I Trad Knowledge 2008, 7:326-329.

61. Slovan A, Paulmurugan R, Wilsand V, Ranjith Sing AJA: Traditional therapeutic uses of animals among tribal population of Tamil Nadu. Ind J Trad Knowledge 2004, 3:206-207.

62. Pieroni A, Grazzani A, Giusti ME: Animal remedies in the folk medical practices of the upper part of the Lucca and Pistoia provinces, Central Italy. Proceedings of the 4th European colloquium of Ethnopharmacology Paris, France; 2002, 371-375.

63. Kunin WE, Lawton JH: Does biodiversity matter? Evaluating the case of conserving species. In Biodiversity: a biology of numbers and differences. Edited by: Gaston KJ. Oxford, Blackwell Sci Publ; 1996:283-308.

64. Cavaliere $C$ : Medicinal use of threatened animal species and the search for botanical alternatives. Herbal Gram 2010, 86:34-49.

65. Labadie RP: Problems and possibilities in the use of traditional drugs. $J$ Ethnopharmacol 1986, 15:221-230

66. Meyer-Rochow VB: Entomophagy and its impact on world cultures: the need for a multidisciplinary approach. In Edible Forest Insects. Edited by: Durst PB, Johnson DV, Leslie RN, Shono K. Bangkok, FAO Publ; 2010:23-36.

67. Mahawar MM, Jaroli DP: Traditional knowledge on zootherapeutic uses of Saharia tribe of Rajasthan, India. J Ethnobiol Ethnomed 2007, 3:25.

68. Patil SH: Ethno-medico-zoological studies on Nadurbar district of Maharashtra. Ind J Trad Knowledge 2003, 2:297-299.

69. Gupta L, Siroli CS, Mistry N, Dixit AM: Use of animals and animal products in traditional health care systems in District Kachch, Gujarat. Ind I Trad Knowledge 2003, 2:346-356.

70. Negi CS, Palyal VS: Traditional uses of animal and animal products in medicine and rituals by the Shoka tribes of District Pithoragarh, Uttaranchal, India. Ethnomed 2007, 1:47-54.

doi:10.1186/1746-4269-7-13

Cite this article as: Chakravorty et al:: Vertebrates used for medicinal purposes by members of the Nyishi and Galo tribes in Arunachal Pradesh (North-East India). Journal of Ethnobiology and Ethnomedicine 2011 7:13.

\section{Submit your next manuscript to BioMed Central and take full advantage of:}

- Convenient online submission

- Thorough peer review

- No space constraints or color figure charges

- Immediate publication on acceptance

- Inclusion in PubMed, CAS, Scopus and Google Scholar

- Research which is freely available for redistribution 